\title{
The Invention of Work in Modernity: Hegel, Marx, and Weber
}

\author{
DANIEL JUST*
}

\begin{abstract}
In the modern era, a wide range of human activities has been redefined as work. This essay traces a genealogy of the modern conception of work, from early Protestant ethic of work as worship of God, through secularization of this ethic and the emergence of the idea of progress, to the later model of work as personal duty and source of stability. Analyzing Hegel, Marx, and Weber's interpretations of the growing centrality of work in the modern epoch, as well as later reflections on these interpretations by Kojève, Arendt, and Foucault, the paper argues that in modernity work is no longer a mere instrument of power and tool for repressing human life, but a mode of power of its own accord: a privileged means of shaping life by cultivating and regulating its productive potential. Modern society is reorganized according to the principles of productivity, efficiency, and economic welfare of population as a whole that recalibrate individual existence and posit virtually all activities as a form of work.
\end{abstract}

\section{Introduction: Modern Work and Its Discontents}

Work is the only law of the world. Life has no other purpose, there is no other reason for existence, we all come into being only to do our share of work and disappear. ${ }^{1}$

When at the close of the nineteenth century Émile Zola celebrated work - for his statement, despite its seemingly despondent tone, was an homage to work, which he believed was a source of stability in the transience and precariousness of human existence - work was already an established social and cultural value. Not everyone accepted this triumph of work. Most notably, Nietzsche condemned the modern glorification of work, calling it "the true vice of the new world" that is quickly spreading to Europe, and warning that now "the never-ceasing talk about the 'blessing of labor' holds everyone in check." According to Nietzsche, leisure became time of recuperation and preparation for more work, and thus not an antithesis of work, but its organic counterpart. ${ }^{3}$ Also Freud wondered whether work made people happy and modern life satisfying. But unlike Nietzsche, Freud was already reconciled with the historical trend. Conceding to the rising presence of work, he accepted it as an inevitable outcome of the human proclivity for safety. This proclivity, according to him, originated in primal man who discovered that "it lay in his own hands, literally, to improve his lot on earth by

* Daniel Just is Assistant Professor in the Department of Political Science at Bilkent University in Turkey, just@bilkent.edu.tr 
working," and who consequently chose to exchange "a portion of his possibilities of happiness for a portion of security." Although for different reasons and with different ramifications, Zola, Freud, and to a lesser extent Nietzsche as well, all agreed that if the growing role of work in modernity involves any notion of happiness, it is a very paradoxical one: as temporary renunciation of happiness, modern work becomes a substitute for happiness, and ultimately its main source.

\section{Weber: The Protestant Ethic of Work and Its Secularization}

Max Weber's magisterial study suggests that the pivotal status of work in the modern era is a product of the development that started with the Protestant schism in the early sixteenth century, continued with the subsequent spread of reformed faiths, and was reified in an increasingly secularized form during the Industrial Revolution. According to Weber, it was the Protestant interest in economic endeavors - especially the Calvinist refocusing of human activities in the direction of private acquisition and the Baptist (particularly the Quakers') emphasis on asceticism as the guiding principle of economic conduct - that paved the way for the central place of work in modernity. ${ }^{5}$

For early Protestants, worship of God through work and active engagement with daily life was a more devout alternative to monastic spirituality and inactive contemplation. Against the medieval view of work as unavoidable necessity, and hence something not to be praised in itself, Protestants introduced work as a virtue and waste of time as a deadly sin. Time was of vital importance for Protestants because human life is short and one needs to use it well in order to succeed in economic pursuits, which are a sign of God's blessing and a guarantee of selection for the afterlife. While the proposition that time is money did not yet apply, it held, as Weber notes, in a certain spiritual sense: "Loss of time through sociability, idle talk, luxury, even more sleep than is necessary for health, six to at most eight hours, is worthy of absolute moral condemnation." Weber quotes from the 1673 Puritan tracts and sermons of Richard Baxter to illustrate this early modern fixation on activity and proper use of time:

\footnotetext{
"Keep up a high esteem of time and be every day more careful that you lose none of your time, than you are that you lose none of your gold and silver. And if vain recreation, dressings, feastings, idle talk, unprofitable company, or sleep be any of them temptations to rob you of any of your time, accordingly heighten your watchfulness". ${ }^{7}$
} 
For Baxter, work protects one from indolence and impropriety literally, an "unclean life" - because without serious work and self-discipline, life lacks grace:

"If God shows you a way in which you may lawfully get more than in another way (without wrong to your soul or to any other), if you refuse this, and choose the less gainful way, you cross one of the ends of your calling, and you refuse to be God's steward, and to accept His gifts and use them for Him, when He requireth it: you may labor to be rich for God". ${ }^{8}$

Everyone, including the rich, has to work. Moreover, everyone must create opportunities to work more and with better results. In other words, one is expected not only to work, but also to enhance one's prospects of working with more success. Weber maintains that this idea of work as God's calling, a commandment to work for the divine glory with an ever increasing success, has far-reaching social and psychological consequences for modernity. ${ }^{9}$

God's call to amass riches in His name is a call to work in the spirit of worldly moderation and self-control in which idleness, spontaneity, and enjoyment of life's sensual riches do not have a place. While wealth is not a problem if it is part of the performance of duty in a calling, it becomes one when it turns into temptation to idleness, enjoyment of life, and accretion of funds for their delayed enjoyment (having enough one day to be able to live without worries, or trying to secure such a life for one's offspring). Fruits of one's labor are not to be enjoyed by those who create them or inherit them because work and its products are a matter of duty. Work, Weber argues, is an end in itself. ${ }^{10}$ There is no endpoint and no occasion for a pause in the process of working and accumulating. Quite the opposite: one's investment of time and effort into work grows in proportion to one's economic success. The greater one's possessions, as Weber points out, the more intense the feeling of responsibility for them, "for holding them undiminished for the glory of God and increasing them by restless effort." ${ }^{11}$ One's commitment must be to work and to multiply one's fortunes, that is, neither to enjoy them nor to invest them into fixed possessions - such as property and land, in the manner of aristocratic class - but to reinvest them into enterprises that will lead to further riches. This early Protestant emphasis on work and renunciation of enjoyment provides a basis for the modern division of labor as a way to augment profit-making activities. Moreover, it fosters the psychological disposition of the modern individual: that "sober, middle-class, self-made man," as Weber describes him, with "formalistic, hard, correct character." ${ }^{12}$

Interestingly enough, the rise of wealth and the strengthening of the middle class that took place in the late eighteenth century did not significantly alter the early Protestant ethic of work analyzed by 
Weber. Although this new development was accompanied by secularization and new comforts unknown to Puritans, the bourgeois emphasis on work implied the same notion of enjoyment - one which is curbed, reserved, and postponed. The main concern remained to multiply wealth in the economically unpredictable environment in which it could quickly diminish, and which therefore demanded disciplined work coupled with parsimony. What was at stake was not just economic wellbeing. As for early Puritans, work was more than a pragmatic venture. It was a social and cultural value. Although things changed with heavy industrialization in the nineteenth century, as the bourgeoisie became a more powerful and prevalent class than before and entrepreneurship turned to bolder and larger scale speculation, even this new commercial imagination, while indeed oriented more towards the future and motivated less by the older accent on caution and earnestness, was nevertheless still driven by the same principles of calculation, utility, and efficiency. As Barrington Moore showed, in the nineteenth century working regularly and scrupulously was still the keystone of a lifestyle that was deemed moral, and thus good, because it was rational and methodical. ${ }^{13}$ Jürgen Kocka confirms that the values of achievement and profit - as well as those that fostered them, such as industriousness, rationality, and emotional control - persisted well into the late nineteenth century, a fact illustrated by Franco Moretti's statistical analysis of nineteenthcentury novels in which the most frequent words associated with bourgeoisie in these texts were "useful," "efficiency," "serious," and "earnest." 14 According to Moretti, these qualities continued to define life both within and beyond the realm of business activities. Seriousness, for example, as an extension and a kind of sublimation of commercial honesty, was a way of coming to terms with reality that was no longer seen as a necessity, but a value. Moretti insists that for a nineteenth-century bourgeois "containing one's immediate desires is not just repression: it is culture." 15

Starting in the late eighteenth century and continuing throughout the following one, serious work, efficient accumulation of wealth, and earnest enlargement of one's possessions was still, as it was for early Protestants, what one was expected to do. In this framework of modern life governed by work, enjoyment was infinitely delayed because steady accumulation, and thus meaningful life, could be assured only through patient work and reinvestment of wealth. As Karl Löwith remarked with respect to the man of the bourgeois epoch, but the statement could have been as easily made by Weber with respect to early Protestants, modern man not only works, but desires to work, because life without work "would seem to him not worth living, lived 'in vain'." 16 
The chief notion that emerges with the gradual process of secularization of the Protestant ethic of work is the idea of progress. The notion of progress that is larger than the lifetime of a single individual extends the Protestant emphasis on work and renunciation of pleasure by attaching work to an investment into the next generation, rather than to personal salvation. The concept of divinity does not disappear, but it does change as a result of increasing secularization and mechanization. As Peter Sloterdijk argued, in the era of mechanization the concept of divinity turns from the biological conception of procreation to that of production, with "the procreating God becoming increasingly a world manufacturer, the original producer." ${ }^{17}$ The modern ideas of progress and production are both a continuation of the Protestant work ethic and a response to it. They are an adaptation of this ethic to the newly arisen need to make oneself at home in the world that no longer has the guarantee of the divine order. As a vehicle of progress, it is work that gives the unhinged life and history an appearance of predictability. In a gesture of "self-assertion," as Hans Blumenberg called it, by which the modern man assumes a place in history and posits himself within the course of historical development - a gesture unimaginable in premodern times when progress and man's place in it were thinkable only as a result of divine intervention - work becomes a way of actively mastering the new world. ${ }^{18}$ It is still salvation through work, including suspended enjoyment and allotment of time into what makes work more productive, that serves as the guideline for action. But now it is no longer because of one's salvation in the afterlife. Salvation now takes place in this world, through what people leave behind as a result of their work and their belief that progress continues after their death, and it will be only later - according to Charles Taylor only much later, in the second half of the twentieth century - when the modern idea of disciplined work as the underpinning of progress disintegrates and when further secularization preserves the work ethic, but not the frugal approach to consumption anymore. ${ }^{19}$

When Weber examines the shift from the early Protestant search for the kingdom of God through work to the later modern worldliness that no longer needs the support of religion, he confirms that the renunciation of enjoyment in later stages of modernity coexists with the principles of self-assertion and investment into individual salvation by way of subsequent generations. He argues that for modern workers, those "sober, conscientious, and unusually industrious workmen" shaped by religious asceticism, work as a calling in the spirit of capitalism is the same as the earlier Puritan work ethic - "only without the religious basis." ${ }^{20}$ This emphasis on continuity (of work and renunciation of enjoyment) in spite of 
change (from personal salvation to salvation through accumulation from generation to generation) reveals an important, even if understated, undercurrent in Weber's analysis of modern work. One of the texts central to Weber's argument is the following passage by John Wesley:

"I fear, wherever riches have increased, the essence of religion has decreased in the same proportion. Therefore I do not see how it is possible, in the nature of things, for any revival of true religion to continue long. For religion must necessarily produce both industry and frugality, and these cannot but produce riches. But as riches increase, so will pride, anger, and love of the world in all its branches. [. . .] So, although the form of religion remains, the spirit is swiftly vanishing away. Is there no way to prevent this - this continual decay of pure religion? We ought not to prevent people from being diligent and frugal; we must exhort all Christians to gain all they can, and to save all they can; that is, in effect, to grow rich". ${ }^{21}$

Weber reproduces this passage in its entirety, italicizing the last sentence so as to draw attention to the fact that the secular version of the Protestant ethic of work not only does not betray the Puritan model of work, but that it is inherent in this model. Nevertheless, Weber curiously omits two concluding sentences from Wesley's text. Where Weber terminates the quote, Wesley continues: "There is one way, and only one, under heaven. If those who gain all they can, and save all they can, will likewise give all they can; then, the more they gain, the more they will grow in grace."22 One can speculate why Weber left out these two sentences, but the most obvious explanation, namely that they did not fit his argument about the Protestant appeal to an uncompromising accumulation, is not the only, or even the most plausible, reason. For Weber, Wesley's insistence on giving, although opposed to accumulation for its own sake, is rendered ineffective and unrealizable precisely by the Protestant ethic of work. If growing in grace depends on increased gains, giving away these gains must be, similarly to enjoyment, postponed. Since one's duty in venerating God is to reinvest work's gains according to one's best economic conscience, one needs to follow, first and foremost, one's obligation to invest work into a better organization of work and more efficient ways of multiplying profits. Even for Wesley, working takes precedence over giving.

The undercurrent that drives Weber's analysis of work is the following question: What is the impulse that sustains the continuity of the early modern notion of work throughout modernity in spite of the sweeping historical changes that come with secularization and industrialization? Weber suggests that this impulse is the effort of the modern individual to overcome the sense of isolation, emptiness, and meaninglessness of the present moment, which is one of the most distinct experiences of the modern era. The 
guarantee that work will have this redeeming function of filling the present with meaning by connecting it to what lies beyond it is, in the case of early Protestants, God and afterlife, and, in the case of secular bourgeoisie, progeny that links one's lifetime to that of the next generation. But Weber does not take a closer look at this impulse. It is Hegel and Marx who do so. Hegel and Marx propose that in the era of no divine assurances, work links the present to the past and the future because it becomes the axis of a new way of shaping the productive potential of human life and the collective welfare of the population as a whole.

\section{Hegel and Marx: Work and the Shift in Forms of Power}

Hegel posits work as the foundation of human culture and its historical evolution. As purposeful shaping by tools, work is a means to attain ends, a "middle term" between humanity and the world. ${ }^{23}$ Unlike the animal, which does not work and which satisfies its needs directly from nature - animal desire is pure negation of objects that are therefore evanescent and lacking in objectivity man's act of taking nature as the object of work is "desire restrained and checked, evanescence delayed and postponed." ${ }^{24}$ For Hegel, this delayed desire that transforms nature into human products is essential to the founding of human consciousness. Man has consciousness, something that is unknown to animals, because work puts him in relation to his products. As man-producer realizes that it is he who is the source of the product's independence as an object, he becomes conscious of his independence as a subject. As the starting point of human consciousness, work is the origin of culture and its subsequent historical development. In Hegel's scenario, the dialectic of work, individual consciousness, and collective human culture starts at the moment of violent imposition of work by the master, who does not work, on the bondsman who works for him. But as Hegel stresses, it is paradoxically the bondsman, not the master, who is the real master of nature. The bondsman is the one who shapes nature by imprinting concrete forms on it in the act of working, thereby creating the human world. ${ }^{25}$ According to Hegel, the modern era begins at the moment when the working bondsman becomes conscious of his position in history as the maker of human society and culture.

Marx's analysis of the role of work in the self-conception of the modern individual follows a similar line of reasoning as Hegel's. Marx, too, believes that people begin to distinguish themselves from animals as soon as they "begin to produce their means of subsistence." ${ }^{26}$ But Marx objects to what he perceives as Hegel's "abstractly mental" approach to work. ${ }^{27}$ According to Marx, Hegel 
reduces work to a spiritual force when he argues that man as spirit (consciousness of objectivized being in its historical becoming) acts through work on nature (that which is opposed to spirit and which sets history in motion by resisting it). Marx insists that in order to explain the role of work in modernity, work must be regarded as concrete rapport with material reality, rather than as an agent of spirit's engagement with its environment. The crux of Marx's argument is his proposition that the modern era relegates concrete work to an aspect of produced value. By making workers sell their work for wages - the amount of which is established by the market that retains a share of the value created by workers - modern capital transforms work into a commodity, an abstract form of "labor power" (Arbeitskraft). ${ }^{28}$ In modern capitalism, labor power, as one's general ability to work, becomes "abstract labor," a valuetransforming activity involved in the manufacturing of products that adds monetary value to things. ${ }^{29}$ Abstract labor is the effect of modern capitalist speculation on work that emphasizes the exchange value of products. As employers speculate how to make profit, they consider not only whether hiring workers for their new venture will accomplish the work this venture will require, but also whether the labor of these workers will add value to the created product and in so doing lead to profit. According to Marx, modern work can no longer be defined by a split into work that is necessary and work that is a surplus. All work is now predicated on the principle of surplus and exposed to increasingly abstract forces.

In both Hegel and Marx's accounts, abstractness and abstraction are the recurring attributes of modern work. As many critics have pointed out - Michel Foucault, for example - the issue at stake when it comes to modern work is not only abstractness of the actual coordinates of work as it manifests itself in the real world. It is not only that in modernity work has become more abstract; the question is also abstraction with respect to the way in which modern work is described and interpreted. Interestingly, the problem of abstraction concerns not only Hegel, but also Marx. Although reproaching Hegel for his abstract approach to work, Marx, according to Foucault, is equally abstract when he discusses modern work as labor power. Instead of concrete work, Marx's conception of work as labor power addresses work that "has been cut off from its human reality, from all its qualitative variables." ${ }^{30}$ In a move that resembles Marx's reproach of Hegel, Foucault suggests that the perspective of concrete human reality is vital to capturing the role of work in modernity and man's place in it, because work "is absolutely not man's concrete essence or man's existence in its concrete form." 31 For Foucault, modern man is not a worker. $\mathrm{He}$ is made into one via an operation that ties him to work and 
that makes him part of the production apparatus within which he works. Although intended as a critique of Marx, Foucault's approach to modern work as a form of power is important because it helps to draw out from Marx's and Hegel's analyses of the place of work in modernity what might not be immediately apparent in them.

According to Foucault, the most significant operation that transforms people into modern workers is control over their time. Unlike feudal society that controlled individuals on the basis of space, modern society cares about their spatial ties only to the extent of claiming their time. Foucault argues that, beginning in the late eighteenth century when the newly introduced politics of health turned poverty into an unacceptable form of idleness that had to be eliminated, modernity adapts people to the needs of modern production by molding their time into labor time. ${ }^{32}$ Modern society mobilizes all of people's available time to the extent that it is no longer just the time of the work day, but the whole lifespan that is now the object of the best possible utilization by the production apparatus. ${ }^{33}$ Foucault illustrates how institutions whose professed function it was to provide protection and security in fact served as a means of ensuring that entire population and the whole time of human existence were inscribed into the labor market. For example, amid the wage raises in France and England in 1840s and 1850 s, the surplus of money was deposited into workers' savings funds, not in order to improve workers' comfort, let alone serve as a buffer to stage strikes, but for future use in case of job loss. This strategy was part of larger forces that redefined modern society along the lines of efficiency and productivity. This strategy bolstered efficiency and strengthened the market's flexibility, as employers needed to hire and dispose of workers freely, without nonetheless letting them die of hunger before they were needed again or elsewhere. ${ }^{34}$

Foucault's insistence on analyzing modern work in concrete forms, as an outcome of forces that regulate work by activating workers and inciting their increased engagement in the act of working, is rooted in his conviction that the uniquely modern type of power is essentially linked to economic concerns. In modernity, power no longer represses life; it supports life and promotes it by cultivating its productive potential. Work becomes a form of investment of the specifically modern type of power in human capital. Differentiating between an early stage of modernity (end of the seventeenth century and the beginning of the next) and its later stage (the second half of the eighteenth century and the following one), Foucault argues that whereas in the earlier stage people were turned into workers by means of disciplinary technologies (e.g., 
spatial distribution of individual bodies, surveillance of these bodies, and drills and exercises that disciplined them), in the second stage new regulatory mechanisms emerged that at first supplemented the older disciplinary mechanisms and later largely replaced them. ${ }^{35}$ Although serving the same purpose of turning people into workers, the new form of power did so, not by disciplining and repressing life, but by nourishing its economic potential. This positive kind of power - positive in terms of producing and productive, not unproblematic - is crucial to modernity because the latter, Foucault claims, "would not have been possible without the controlled insertion of bodies into the machinery of production and the adjustment of the phenomena of population to economic processes." 36

The main difference between the older repressive power and the new "biopower" when it comes to work is that while the former was concerned with the immediate value of individual body for work, the latter focuses on regulating entire population according to the value of economic productivity. Modern biopower takes for its object not the actual work of individual workers, but the potential of population as such to work. Various mechanisms were mobilized to stimulate this potential, such as statistical data (birth rates, mortality rates, and longevity predictions), safety policies, charities for the old and incapacitated, and health care schemes that emphasized therapeutic rather than normalizing procedures. ${ }^{37}$ The many means of promoting work and productivity directly - above all, the advancement of education and introduction of student loans to enable people to acquire needed work qualifications - were supplemented by other measures that pertained to work less directly, but that were nevertheless part of the same power operation of fashioning people as workers and shaping human life through work. Mechanisms, such as hygienic rules, were devised to secure the optimal age of population; pension funds, saving funds, and other incentives to save were created so as to foster a workforce that was more flexible; and tax deductions, maternity leaves, and the establishment of day care were intended to encourage reproduction and make workers more readily available. ${ }^{38}$ All these new mechanisms that composed modern biopower contributed to a single goal: an economically more efficient and productive society.

Foucault's examination of work as a form of power offers an innovative perspective on modern work. But while critical of Marx, this perspective is not as adverse to Marx as Foucault presents it. Marx surely would not be opposed to analyzing work by looking at operations that bind people to the apparatus of production. But what is even more intriguing is that Foucault presents the effects of these operations by returning to Marx's formulations. He argues, 
for instance, that the operation that inaugurated modern industrial society consisted of two acts: "First, individuals' time must be put on the market, offered to those wishing to buy it, and buy it in exchange for a wage; and, second, their time must be transformed into labor time." 39 Curiously, the reproach that Marx transforms concrete work into abstract labor power is absent. When Foucault suggests that "the function of transforming the body into labor power corresponds to the function of transforming time into labor time," he is essentially paraphrasing Marx. ${ }^{40}$ While indeed putting more emphasis than Marx on how workers responded to these trends and how they became personally invested in mechanisms of allocating their time, Foucault nonetheless admits that the turning of work into abstract labor power is not a result of Marx's perspective on the place of work in modernity, but the effect of actual forces in modern society. In both accounts, as well as in Hegel's, abstractness emerges as an inescapable trait of modernity itself.

When compared to the ancien régime of the Middle Ages, abstractness stands out as the most distinctive feature of the modern era. Aaron Gurevich and Jacques Le Goff maintain that the idea of abstract time, which served as a catalyst for other forms of abstractness in modernity, would have been inconceivable in the ancien régime. ${ }^{41}$ By the end of the eighteenth century, abstractness permeated all strata of modern society, becoming part of both the macro-level of economy and the state, and the micro-level of everyday life of individuals and families. Rules of precision, numbers, and abstract measurements that were first introduced in the sphere of economy were adopted as practical tools to make daily life more orderly. Teaching households important lessons, such as keeping a track of finances, these rules became a routine that took over non-financial matters as well, such as keeping a track of events in everyday life (e.g., records of inoculations, sent letters, and received and given presents) in "a kind of profit and loss ledger of family and social life," as Leonore Davidoff and Catherine Hall put it. ${ }^{42}$ This turn to abstractness, its implementation in everyday life, as well as the more general shift in the apprehension of time described by E. P. Thompson, had an enormous impact on work and work discipline. ${ }^{43}$ These changes were instrumental in radically transforming the perception of the human body. By the end of the nineteenth century, the human body became a focal point of such a level of abstractness that workers were now regarded as human machines. As Anson Rabinbach showed, the budding discipline of "ergonomy," which propounded a quantitative model of the economy of energy that subordinated all social activities of these human machines to the objective of maximizing output, advocated various modifications in the work routine, as well as in 
leisure activities and even workers' diet, in order to ensure more efficient production. ${ }^{44}$ The influence of this fantasy of reciprocity between bodies and machines posited by the new "science" of ergonomy went well beyond the realm of the economics of work. As Mark Seltzer demonstrated, this fantasy entered a popular awareness after featuring prominently in late nineteenth-century literature. ${ }^{45}$ What all these studies - from Gurevich and Le Goff, through Thompson, to Rabinbach and Seltzer - reveal is that abstractness is not a mere by-product of, let alone a distortion perpetuated by, critical approaches to modern work. Abstractness is a tangible material force and a major attribute of modernity that significantly impacted on work.

\section{Critical Strategies of Inquiry into the Role of Work in Modernity}

Hegel, Marx, and Weber's main contribution to the issue of turning people into modern workers is their revelation of how work operates as a social value and organizing principle of modern "material life" - that infra-economy of goods and practices, as Fernand Braudel understood it, that gives concrete form to people's everyday existence. ${ }^{46}$ The key questions for Hegel, Marx, and Weber are the following: How do modern individuals become endowed with their social roles and transformed into workers? How these changes that take place in real life are presented, interpreted, and understood, both at the collective and personal level? The emphasis in these questions is less on challenging specific aspects of modern work (such as treatment of workers, levels of salaries, and quality of working conditions) - although these certainly remain relevant, particularly for Marx - than on bringing to light contradictions generated by the place of work in modern society. The most important of these contradictions, and the principal observation made by Hegel, Marx, and Weber with respect to modern work, is that the latter functions as both the cause and the cure for alienation. Hegel, Marx, and Weber suggest that the modern process of uprooting traditional guarantees, which in the ancien régime gave life meaning that redeemed the isolation of the present moment by linking it to something beyond it, delegates the new role of this guarantee of meaning to work; at the same time, however, work is the reason why this new guarantee is needed in the first place.

As Hegel notes, the modern era of machines neither reduces work nor de-alienates the act of working. In fact, the opposite is true, because "the more mechanical work becomes, the less value it has, and the more the individual must work." 47 Similarly to Weber's argument that early Protestants had to work regardless of whether 
they were rich or poor, Hegel insists that everyone - workers as well as the bourgeoisie - is subject to this increase. For Hegel, this cannot be otherwise because even though the modern state is no longer based on the master-bondsman opposition, it is not yet a state in which work is done for the community and not capital. Envisioning a state in which people are reconciled with everything, Hegel postulates this state as the objective manifestation of the subjective condition that he calls "wise man." In Alexandre Kojève's account, wise man is someone who is "fully and perfectly selfconscious," "the man who wants nothing, who desires nothing," who "wants to change nothing, either in himself or outside of himself [and who] therefore does not act." 48 In other words, wise man no longer works. With him, work as an instrument of the fight against nature comes to a halt. As work ceases to define human activities, it ceases to define people. The act of working is still carried out for the sake of the survival of community, but society is no longer structured around work. Kojève likens the sort of work that takes place at the moment when work stops defining society to the way animals take care of their necessities. At this point, he argues, people "construct their edifices and works of art as birds build their nests and spiders spin their webs." 49

Kojève's metaphor of animal fabrication that marks the end of work as the central organizing principle of modern society resurfaces in Hannah Arendt's reading of Marx. According to Arendt, Marx imagines that at this moment all human activities derive "as naturally from human 'nature' as the secretion of wax by bees for making the honeycomb; to live and to labor for life will have become one and the same, and life will no longer "begin for him [the laborer] where this activity [of laboring] ceases'."50 In both Kojève's and Arendt's portrayals, the end of work means the end of modernity, which in turn means that life and work merge together, with people looking after themselves in the manner of birds, bees, and spiders. However, there is one important difference between the two interpretations (leaving aside the obvious fact that Kojève's reading of Hegel is an exposé, even if a very idiosyncratic one, while Arendt's take on Marx is a critique). The crucial difference is that whereas Kojève argues that life takes over work by pushing it to the minimum - he insists that people at this point "work as little as possible" ${ }^{1}$ - Arendt suggests that life and work at this point in history simply coincide. For Arendt, work becomes a natural act. Arendt's reading is problematic, among other reasons, because in the passage in the first volume of Capital, in which Marx discusses the work of bees and distinguishes it from the work of an architect who first builds cells in his mind and only then actualizes in reality what he first conceived as a mental project, this distinction is 
immediately overturned, as Moishe Postone notes, with the argument that in modernity any aspect of work that appears to be exclusively human, such as purposiveness, is an attribute of capital. $^{52}$

Unlike Kojève's reading of Hegel's idea of the end of work, Arendt's reading of the same idea in Marx emphasizes a qualitative shift in the direction of work's de-alienation, but no quantitative adjustments. Beside the passage from Capital, Arendt's conclusion is based on the following section from Marx's "Wage, Labor and Capital":

The worker, who for twelve hours weaves, spins, drills, turns, builds, shovels, breaks stones, carries loads, etc. - does he consider this twelve hours' weaving, spinning, drilling, turning, building, shoveling, stone breaking as a manifestation of his life, as life? On the contrary, life begins for him where this activity ceases. ${ }^{53}$

Identifying alienated work as the cause of the corrosion of worker's life, Arendt confines Marx's analysis of modern work to a political plea for work's de-alienation. She presents Marx's argument as a call to surmount the separation between work and life, and reach a production that would be animal-like and natural.

It is true that Marx's early works were driven by the vision of natural production and incitement of social change that would precipitate it. But the purpose for introducing the notion of work's end in his later texts is less to picture the event of work's de-alienation, than to describe the specificity of modern society. Marx's theorization of de-alienation and the notion of the end of work are critical tools designed to bring to the fore the way work operates as a value which determines modern life and shapes it into its current form. When Marx argues that for modern workers life begins when their twelve-hour shift ends, the issue he raises is irreducible to political call for an improvement of their working conditions. As we saw with Weber and Hegel, also for Marx the problem is not only alienated work. As the third volume of Capital makes it clear, work as such is a problem. Replacing the term "life," which in "Wage, Labor and Capital" is opposed to alienated production, with the term "realm of freedom," Marx posits the latter against material production in general. He argues that the realm of freedom begins where work "determined by necessity and mundane considerations ceases." ${ }^{54}$ Admittedly, the third volume of Capital neither defines freedom nor explicitly discusses the meaning of the term "realm of freedom." As Jan Kandiyali has recently pointed out, the result of this conceptual vagueness is the fact that the notion of the realm of freedom, in spite of being opposed to the notion of the realm of necessity, does not rule out a possibility of varying degrees 
of freedom within the realm of necessity, because each realm entails a different type of freedom: whereas freedom in the realm of necessity designates collective ability of people within a specific mode of production to control their economic activity, rather than being ruled by external forces, the realm of freedom signifies selfrealization and development of one's distinctly human potentialities outside the realm of necessity and economic activity. ${ }^{55}$ In other words, even for late Marx there are modes of production in which work is less alienated and less adverse to freedom than in others. However, it needs to be underscored that while Marx's argument allows for a possibility of work's de-alienation that would make humankind reach a certain level of freedom even while working, this type of freedom pertains only to a freer way of satisfying physical needs. Unlike Marx's earlier texts, in which human beings and their freedom is presented as inextricable from work, and in which, consequently, the main question is political change and induction of a different mode of production wherein work would become meaningful, in the third volume of Capital real freedom lies outside the realm of necessity and economic activity - that is, outside of work.

Similarly to Kojève's interpretation of Hegel and his argument about working as little as possible, in the third volume of Capital Marx insists that for the realm of freedom to flourish "the reduction of the working day is the basic prerequisite." ${ }^{56}$ There have been numerous proposals to reduce the number of working hours, both in Marx's time and thereafter. For example, in 1883 Paul Lafargue provocatively called for a law that would forbid people to work more than three hours a day. ${ }^{57}$ This call was later reiterated by Raoul Vaneigem, who argued that three hours of work per day would be enough to sustain society with the technology available in 1938, and echoed by both Henri Lefebvre, who justified it by the increasing broadening and diversification of modern productive forces, and Guy Debord, who demanded that modern technology be used to untie people from work, rather than to increase their standard of living. ${ }^{58}$ But beyond serving as an inspiration for different political appeals for change, Marx's late notion of work's reduction should be seen - similarly to Hegel's idea of the end of work - as an instrument of critical analysis in his inquiry into the nature of modernity.

Hegel's and Marx's concepts of the realm of freedom, reduction of work, and the end of work are critical strategies of exposing the dominance of work in the modern era, because these concepts draw attention to the resistance of modern society to any questioning of work and its status. As Garry Cross argued, the nineteenth-century liberal state was particularly hostile to this questioning and to any 
calls to reduce working hours, as long hours and low wages were deemed necessary for higher output and growth. ${ }^{59}$ Shorter hours were feared to raise unit costs, disrupt scheduling, and limit flexibility in responding to orders, which, together with raises in wages as a result of intensifying competition, would jeopardize profit. Cross surmises that, if pressed, nineteenth-century employers were more likely to raise wages than shorten the workday because the former concession was more permissible to a possible later reversal. ${ }^{60}$ This competitive pressure to extend the workday, instead of shortening it, was further fueled by the expanding modernization, as expensive machinery had to be utilized to the maximum, which other inventions, such as gas lamps, now made possible by eliminating natural limits on the workday. ${ }^{61}$ Within this social, political, and economic context, the notions of de-alienation of work, reduction of working hours, and the end of work were less prognostic statements and more diagnostic attempts to draw out and make more apparent the growing centrality of work in modern society.

\section{Conclusion: Work as an Invention of Modernity}

What is the purpose of these unheard-of constructions [factories, bridges, railways, canals, telegraph lines, furnaces]? In large part, they directly serve production. In part, they serve transport and trade, and thus indirectly production. In part, they serve administration, domicile and health care, and thus predominantly production. In part, they serve science, art, technology, education, recreation, and thus indirectly once again production. ${ }^{6}$

Making resources an object of explicit calculations and mechanisms of human life an issue of production, productivity, and efficiency, modern society radically changes ways in which power has hitherto operated. Modern power no longer deals with legal subjects over whom coercion is exercised with the ultimate authority of death. As Foucault demonstrated, modern power deals with living beings, their productivity, and their usefulness to the economic welfare of the population as a whole. ${ }^{63}$ In modernity, the lives of everyone, not just those concerned with financial gain, are determined by work and economic valuation. Weber laments that while "the Puritan wanted to work in a calling, we are forced to do so." 64

André Gorz is right when he declares that 'what we call 'work' is an invention of modernity." ${ }^{65}$ But he is wrong to explain this invention by arguing that whereas in the ancien régime work was "a way of life," in modern times it is "just a means of earning a living." 66 In modernity, work is above all a way of life. The modern era is shaped 
by work and governed by values and practices anchored in it. Work is a privileged conduit of the specifically modern form power that includes various disciplining institutions and normative mechanisms (factory, working hours, wages, and policies of the liberal state); regulative knowledge linked to these institutions (discourses of economics, ergonomics, and economy of energy); as well as the corresponding social and cultural values (prosperity, efficiency, achievement, seriousness, industriousness, and rationality) that are diffused and either internalized or resisted. If we do not limit modernity to an evolutionary stage that all societies are destined to reach at some point, but instead understand it, as Postone suggests, as "a specific form of social life that originated in western Europe and has developed into a complex global system," then, Hegel, Marx, and Weber's analyses of work appear less as a denunciation of particular forms of exploitation within the modern society, and more as a critique of the nature of modernity itself. ${ }^{67}$ Although work in their texts does not always function as a steady concept, and although the family resemblance of these thinkers as theorists of modernity is loose as well, what their analyses of modern work share is the general framework of interpretation. Hegel, Marx, and Weber do not condemn work's alienation and criticize work's private factors from the point of view of its social factors. With the exception of the early Marx, they do not posit some authentic model of work that modernity distorts. Theirs is not a critique of modern society from the standpoint of work, but, as Postone remarks in reference to Marx, an assessment of the socially constitutive role played by work in that society - a society in which work itself is a vehicle of social domination. ${ }^{68}$

The paradox of modernity is that the practice of spiritualizing work and endowing it with redemptive powers, although driven by the ideal of the present moment that is full, complete, and meaningful on its own, generates a time that is increasingly more accelerating and always ahead of itself. In modernity, the present escapes more than ever before. As one works for the future in an ever more frantic tempo, one pushes the present moment progressively further out of reach. Rather than security, as Freud still believed, modern work engenders a state of permanent insecurity. Reminiscent of Adorno and Horkheimer's argument about the logic of the Enlightenment - which, although set to oppose irrationality, comes to an ironic denouement in the irrational extremes to which it leads (e.g., totalitarianism, Nazism, culture industry, and destruction of nature) - modern work expedites, instead of attenuating, the loss of traditional guarantees that secured life in the premodern era. Hegel, Marx, and Weber suggest that the main concern regarding modern work is not that it is prescribed as a 
remedy that fails to cure alienation. The main concern is that modernity radically reorganizes society according to the principles of efficiency, productivity, and economic welfare of population, and that by recalibrating individual existence according to these same principles, it effectively redefines all human activities as a form of work. In modernity, people no longer work only when performing the act of working. They invest their time as work, produce themselves by working, and relate to their life and the world through work.

\section{Notes}

${ }^{1}$ Émile Zola, "Discours au Banquet de l'Association générale des étudiants, 18 mai 1893," in OEuvres complètes, edited by Henri Mitterand, 15 vols (Paris: Cercle du Livre Précieux, 1966-1969), XII, 677-83 (682) (translation mine).

${ }^{2}$ Friedrich Nietzsche, The Gay Science With a Prelude in German Rhymes and an Appendix of Songs [1882], edited by Bernard Williams, translated by Josefine Nauckhoff (Cambridge: Cambridge University Press, 2001), 183; Friedrich Nietzsche, The Dawn of Day [1881], translated by John McFarland Kennedy (New York: The MacMillan Company, 1911), 176.

${ }^{3}$ Nietzsche, The Gay Science, 184.

${ }^{4}$ Sigmund Freud, Civilization and Its Discontents [1930], translated by James Strachey (New York: W. W. Norton \& Company, 1989), 53, 73.

${ }^{5}$ It should be pointed out that although Weber focuses on the significance of religious ideas for culture, history, and social and economic conditions, at the end of his study he shows that he is aware that the relationship was likely not one-sided: that, in other words, emerging capitalism also impacted on the development of Protestantism, an influence that he urges to be further investigated. Max Weber, The Protestant Ethic and the Spirit of Capitalism [1904-1905], translated by Talcott Parsons (New York: Charles Scribner's Sons, 1958), 183. As Giorgio Agamben has recently shown, the directive against loss of time and its link to work was in place already in the Middle Ages. According to Agamben, the medieval monastic spirituality was far from inactive. Its strict chronometric scansion of time was very closely connected to work, with the monk's every activity of manual labor being utilized as a means of intensifying spiritual exercises and religious experience. Giorgio Agamben, The Highest Poverty: Monastic Rules and Form-of-Life, translated by Adam Kotsko (Stanford: Stanford University Press, 2013), 18-27.

${ }^{6}$ Weber, The Protestant Ethic, 157.

7 Weber, The Protestant Ethic, 261, note 14.

${ }^{8}$ Weber, The Protestant Ethic, 162.

${ }^{9}$ Weber, The Protestant Ethic, 160.

${ }^{10}$ Weber, The Protestant Ethic, 62.

${ }^{11}$ Weber, The Protestant Ethic, 170.

12 Weber, The Protestant Ethic, 163, 164.

${ }^{13}$ Barrington Moore, Moral Aspects of Economic Growth (Ithaca: Cornell University Press, 1998), 39. 
14 Jürgen Kocka, Industrial Culture and Bourgeois Society: Business, Labor, and Bureaucracy in Modern Germany (Oxford: Berghahn Books, 1999), 234. Franco Moretti, The Bourgeois: Between History and Literature (London: Verso, 2013), 35-43, 67-73, 131-134. For an opposing view to Kocka, which suggests that the second half on the nineteenth century was already dominated by values, such as speculation and imagination, that departed from the strict rationality and methodicity of the first half of the century, see Joseph A. Schumpeter, Capitalism, Socialism and Democracy (New York: HarperCollins, 2008), 81-86. Schumpeter's view is part of a larger argument in favor of a less homogeneous image of modernity and a more gradual transition from premodernity to modernity. The former aspect of this argument is developed by Eric J. Hobsbawm, who claims that as a result of the rise of the rentier class, values in the second half of the nineteenth century changed, as the concern was no longer to combine earning and spending money in a morally proper way, but demonstrating success by spending alone. The latter aspect is elaborated by Arno Mayer, who emphasizes the persistence of the old regime throughout modernity, with the newly formed bourgeois class drawing ever closer to the old ruling classes, instead of contesting them. Eric J. Hobsbawm, The Age of Capital, 1848-1875 (New York: Vintage Books, 1996), 236-37. Arno Mayer, The Persistence of the Old Regime: Europe to the Great War (New York: Pantheon Books, 1981), 45.

15 Moretti, The Bourgeois, 87.

${ }^{16}$ Karl Löwith, From Nietzsche to Hegel: The Revolution in NineteenthCentury Thought, translated by David E. Green (Garden City: Anchor Books, 1967), 261.

17 Peter Sloterdijk, Critique of Cynical Reason, translated by Michael Eldred (Minneapolis: University of Minnesota Press, 1987), 27.

${ }^{18}$ Hans Blumenberg, The Legitimacy of the Modern Age, translated by Robert M. Wallace (Cambridge: The MIT Press, 1985), 138. Blumenberg questions the secularization thesis, which he associates with Heidegger and Schmitt's argument that modernity is a continuation of premodernity in a disguised (i.e., secularized) form, with the bourgeois idea of work and progress being a secular counterpart to Christian eschatology, as a misinterpretation of both the premodern (Christian) doctrine and its modern (secular) version. According to Blumenberg, the idea of progress is unique to modernity because Christian doctrine, due to the eschatological disappointment of early church fathers that apocalypse did not take place and that the world continued, emphasized personal rather than collective salvation. Blumenberg, The Legitimacy of the Modern Age, 27-35.

19 Charles Taylor, A Secular Age (Cambridge: Harvard University Press, 2007), 473-504.

20 Weber, The Protestant Ethic, 177, 180.

21 Weber, The Protestant Ethic, 175 (italics added by Weber).

22 John Wesley, "Thoughts Upon Methodism" [1786], in The Works of the Rev. John Wesley, edited by Joseph Benson, 17 vols. (London: Thomas Cordeux, 1809-1818), XV, 330-33 (333) (italics in the original).

${ }^{23}$ Georg Wilhelm Friedrich Hegel, Jenenser Realphilosophie [18031804], edited by Johannes Hoffmeister, 2 vols. (Leipzig: Felix Meiner, 1932), I, 203 (translation mine).

${ }^{24}$ Georg Wilhelm Friedrich Hegel, The Phenomenology of Mind [1807], translated by James B. Baillie (New York: Harper Torchbooks, 1967), 238.

${ }^{25}$ Hegel, The Phenomenology of Mind, 237. 
${ }^{26}$ Karl Marx and Friedrich Engels, The German Ideology [1845-1846], translated by William Lough (Amherst: Prometheus Books, 1998), 37 (italics in the original).

27 Karl Marx, Economic and Philosophic Manuscripts of 1844, translated by Martin Milligan (Amherst: Prometheus Books, 1988), 150 (italics in the original).

28 Karl Marx, Capital: A Critique of Political Economy, Vol. 1 [1867], translated by Ben Fowkes (London: Penguin, 1990), 270-280.

29 Marx, Capital, Vol. 1, 125-137.

30 Michel Foucault, The Birth of Biopolitics: Lectures at Collège de France, 1978-1979, edited by Michel Senellard, translated by Graham Burchell (Basingstoke: Palgrave Macmillan, 2008), 221. For a more thorough discussion of Foucault's analysis of the role of work in modernity and its transformation in postmodernity, see Daniel Just, "A Biopolitics of Immaterial Labor," Political Studies (forthcoming).

${ }^{31}$ Michel Foucault, "Truth and Juridical Forms," in Power. The Essential Works of Foucault, Vol. 3, edited by James D. Faubion, translated by Robert Hurley (New York: The New Press, 2001), 1-89 (86).

32 Michel Foucault, "The Politics of Health in the Eighteenth Century," in Power. The Essential Works of Foucault, Vol. 3, 90-105 (93).

${ }^{33}$ Foucault, "Truth and Juridical Forms," 81.

${ }^{34}$ Foucault, "Truth and Juridical Forms," 81.

${ }^{35}$ Michel Foucault, Society Must Be Defended: Lectures at the Collège de France, 1975-1976, translated by David Macey (New York: Picador, 2003), 249-250. Elsewhere Foucault suggests that in certain areas of modern society the mechanism by which the biopolitical shaping of human life has mobilized work as a life-producing force continued to rely, at least in part, on disciplinary methods. Symptomatically, work was crucial to the "technique of improvement" of convicts, who by the early nineteenth century ceased to be bodies to be punished and became potentially productive members of society who needed to be corrected, cured, and "reclaimed." Michel Foucault, Discipline and Punish: The Birth of the Prison, translated by Alan Sheridan (New York: Vintage Books, 1995), 10.

${ }^{36}$ Michel Foucault, The History of Sexuality, Vol. 1: An Introduction, translated by Robert Hurley (New York: Pantheon Books, 1978), 141.

${ }^{37}$ See Foucault, Society Must Be Defended, 242-244; and Foucault, "The Politics of Health in the Eighteenth Century," 104.

${ }^{38}$ Foucault, Society Must Be Defended, 251.

${ }^{39}$ Foucault, "Truth and Juridical Forms," 80.

${ }^{40}$ Foucault, "Truth and Juridical Forms," 82.

${ }^{41}$ See Aaron J. Gurevich, "Time as a Problem of Cultural History," in Cultures and Time, edited by Louis Gardet (Paris: The Unesco Press, 1976), 229-243; Jacques Le Goff, "Merchant's Time and Church's Time in the Middle Ages," in Time, Work, and Culture in the Middle Ages, translated by Arthur Goldhammer (Chicago: University of Chicago Press, 1980), 29-42; and Jacques Le Goff, "Labor Time in the 'Crisis' of the Fourteenth Century," in Time, Work, and Culture in the Middle Ages, 43-52.

${ }^{42}$ Leonore Davidoff and Catherine Hall, Family Fortunes: Men and Women of the English Middle Class, 1780-1850 (London: Routledge, 2007), 367.

${ }^{43}$ E. P. Thompson, "Time, Work-Discipline and Industrial Capitalism," Past and Present 38 (1967): 56-97.

${ }^{44}$ Anson Rabinbach, The Human Motor: Energy, Fatigue, and the Origins of Modernity (Berkeley: University of California Press, 1992), 4-5. 
${ }^{45}$ Mark Seltzer, Bodies and Machines (New York: Routledge, 1992), 57.

${ }^{46}$ Fernand Braudel, Civilization and Capitalism $15 t^{\text {h- }} 18 t^{\text {h }}$ Century, Vol. I: The Structures of Everyday Life, translated by Siân Reynolds (New York: Harper and Row, 1981), 23-24.

${ }^{47}$ Hegel, Jenenser Realphilosophie, 237 (translation mine).

${ }^{48}$ Alexandre Kojève, Introduction to the Reading of Hegel: Lectures on the Phenomenology of Spirit, edited by Allan Bloom, translated by James $\mathrm{H}$. Nichols (Ithaca: Cornell University Press, 1980), 76, 77 (italics in the original).

${ }^{49}$ Kojève, Introduction to the Reading of Hegel, 159, note 6.

${ }^{50}$ Hannah Arendt, The Human Condition (Chicago: University of Chicago Press, 1958), 89, note 21.

${ }^{51}$ Kojève, Introduction to the Reading of Hegel, 159, note 6.

${ }^{52}$ Moishe Postone, Time, Labor, and Social Domination: A Reinterpretation of Marx's Critical Theory (Cambridge: Cambridge University Press, 1993), 279.

${ }^{53}$ Karl Marx, "Wage, Labour and Capital" [1847], in Marx-Engels Reader, edited and translated by Robert C. Tucker (New York: W. W. Norton \& Company, 1978), 205.

${ }^{54}$ Karl Marx, Capital: A Critique of Political Economy, Vol. 3 [1894], translated by David Fernbach (London: Penguin, 1993), 959.

55 Jan Kandiyali, "Freedom and Necessity in Marx's Account of Communism," British Journal for the History of Philosophy 22 (2014): 104-123 (109).

${ }^{56}$ Marx, Capital: A Critique of Political Economy, Vol. 3, 959.

${ }^{57}$ Paul Lafargue, The Right to Be Lazy and Other Studies, translated by Charles H. Kerr (Charleston: Nabu Press, 2010), 47.

${ }^{58}$ Raoul Vaneigem, The Revolution of Everyday Life, translated by Donald Nicholson-Smith (Wellington: Rebel Press, 2003), 55; Henri Lefebvre, Critique of Everyday Life, Vol. 1, translated by John Moore (London: Verso, 2008), 175; Guy Debord, The Society of the Spectacle, translated by Fredy Perlman and Jon Supak (Detroit: Black and Red Press, 1970), 65. Interestingly, also Stalin proposed a plan to shorten the working day to six, and subsequently five hours. Joseph Stalin, Economic Problems of Socialism in the U.S.S.R., edited and translated by Alexander Trachtenberg (New York: International Publishers, 1952), 53. However, Stalin's plan was to invest the time saved from work to practical ends (political and educational), and was therefore, as Georges Bataille pointed out, part of the modern paradigm of utility and productivity. This argument was recently revisited by Peter Beilharz, who showed that both Stalin and Lenin politicized work by making it an issue of class, thereby accentuating the modern trend of foregrounding work and turning it into a force of industrialization and militarization. See Georges Bataille, The Accursed Share, Vols. 2 and 3, translated by Robert Hurley (New York: Zone Books, 1993), 299; and Peter Beilharz, Socialism and Modernity (Minneapolis: University of Minnesota Press, 2009), 148. A similarly increased emphasis on work occurred under Nazism, even if for different reasons. According to Adam Tooze, the rationale behind the Nazi doctrine of work was to boost German economy that was felt to be threatened by the increasing economic dominance of the United States, although others, such as Werner Hamacher, stress ideological reasons, specifically Hitler's vision of attaining a thoroughly fused type of community that would banish otherness and produce itself organically through collective work. See Adam Tooze, The 
Wages of Destruction: The Making and Breaking of the Nazi Economy (London: Penguin, 2006), 37-66; and Werner Hamacher, "Working Through Working," Modernism/modernity 3 (1996): 23-56 (26).

${ }^{59}$ Gary Cross, A Quest for Time: The Reduction of Work in Britain and France, 1840-1940 (Berkeley: University of California Press, 1989), 23.

${ }^{60}$ Gary Cross, "Worktime and Industrialization: An Introduction," in Worktime and Industrialization: An International History, edited by Gary Cross (Philadelphia: Temple University Press, 1988), 11.

${ }^{61}$ Cross, A Quest for Time, 15.

${ }^{62}$ Walter Rathenau, On the Critique of the Times [1912], cited in Peter Sloterdijk, Critique of Cynical Reason, 436-437.

${ }^{63}$ According to Foucault, it is no accident that the end of the eighteenth century was the time of the dawn of modern biopower and the attendant paradigm of work, as well as the moment of acceleration of the process of exclusion of death from both private and public life. Before this moment, death was a glorious phenomenon marked by personal rituals (testaments, last words, final wishes, and periods of mourning) and public spectacles (tortures and executions). With the emergence of biopower, death ceases to be this grand ceremony and dispensation of death the main principle of investing power in human capital. Foucault, Society Must Be Defended, 247.

${ }^{64}$ Weber, Ethic, 181.

${ }^{65}$ André Gorz, Critique of Economic Reason (London: Verso, 1989), 13 (translation modified).

${ }^{66}$ Gorz, Critique of Economic Reason, 16.

${ }^{67}$ Postone, Time, Labor, and Social Domination, 4.

${ }^{68}$ Postone, Time, Labor, and Social Domination, 303. 